\title{
Ultrasonic slurry sampling combined with total reflection X-ray spectrometry for multielemental analysis of coastal sediments in a ria system.
}

\author{
M.A. Álvarez-Vázquez ${ }^{a, b}$, C. Bendicho ${ }^{a *}$ and R. Prego ${ }^{b}$ \\ a Departamento de Química Analítica y Alimentaria, Facultad de Química, Universidad de Vigo. \\ Campus As Lagoas-Marcosende s/n, 36310 Vigo, Spain. \\ ${ }^{\mathrm{b}}$ Marine Biogeochemistry Group, Marine Research Institute (CSIC). Eduardo Cabello 6, E-36208 \\ Vigo, Spain.
}

*Corresponding author; E-mail: Bendicho@uvigo.es

AbStRAct. An increased concern on environmental issues has arisen in recent decades. Human activities have a great impact on the environment, efficient methodologies being needed for quick assessment of possible contamination sources and their effects. This paper describes a fast method for analysis of sediments by Total Reflection X-Ray Fluorescence (TXRF) using a simple and rapid sample preparation approach, i.e., Ultrasonic Probe Slurry Sampling (UPSS), as an alternative to the digestion of samples. UPSS involves minimal consumption of sample and reagents within the range of microanalysis. A case study focused on a coastal area (Ria of Arousa, NW Spain) is presented. The simultaneous determination of 10 elements ( $\mathrm{Ti}, \mathrm{V}, \mathrm{Mn}, \mathrm{Fe}, \mathrm{Cu}, \mathrm{Zn}, \mathrm{As}, \mathrm{Rb}, \mathrm{Sr}$ and $\mathrm{Pb}$ ) was accomplished by UPSS-TXRF. Method validation was performed by analyzing several certified reference materials. Distribution patterns, natural background levels and enrichment factors that are indicative of contamination for those elements, were obtained. Application of a multivariate chemometric technique, i.e., principal component analysis (PCA), allowed assessing the origin of trace metals in sediments of the Ria of Arousa. 
Keywords: TXRF; metals; background concentration; contamination; Arousa, Spain.

\section{INTRODUCTION}

The northwest margin of the Iberian Peninsula is a coastal ria system integrated by up of eighteen Galician rias, which has been defined by Evans and Prego [1] as incised valleys where the estuarine zone can move according to environmental changes. The Galician rias are among the most important areas in the world for fishing and shell-fishing [2], due to the high primary production $[3,4]$ that occurs greatly influenced by the coastal upwelling. Upwelling events of Eastern North Atlantic Central Water usually develop from April to October [5] and transport of nutrients into the rias occur [6]. Moreover, the shore of rias is an important support for human and industrial settlements, so rias are exposed to a high environmental impact due to urban and industrial discharges, as well as other activities such as sailing and shipping [7,8]. This anthropogenic influence can modify the natural biogeochemical processes of trace elements as a result of contamination [9], which enters the biological cycles and is reflected in the ria sediments. In this way, sediments are usually used to identify contamination sources and to evaluate the environmental quality of aquatic systems [10]. However major, minor and trace elements accumulation in coastal sediments can also occur as a result of natural processes such as alochthonous inputs, supplied through fluvial loads principally, or autochthonous inputs by plankton fall [11]. 
For these reasons, the quantification of trace elements in the sedimentary reservoir and the identification of their continental, marine or anthropogenic sources is of paramount importance. Metals in sediment samples are typically determined by Atomic Absorption Spectrometry (AAS) with Flame or Electrothermal Atomization [12], and more recently, by Inductively Coupled Plasma Atomic Emission Spectrometry (ICP-AES) [13] or Inductively Coupled Plasma Mass Spectrometry (ICP-MS) [14]. The above techniques were mainly applied to the sediments of Galician rias in a non-systematic way, that is, different sedimentary fractions and digestion methodologies with a total or partial digestion were involved. So, there is an urgent need to standardize procedures and assess analytical accuracy with certificate reference materials so that results can be compared among the scientific community and produce reliable results [9].

Techniques based on X-ray fluorescence (XRF), and especially, Total Reflection X-Ray Fluorescence (TXRF), offer an alternative to be taken into account for a systematic and quick sediment analysis. TXRF has the ability to detect almost all the elements from the periodic system, from Boron to Uranium [15]; due to its total reflection effect, detection limits are improved by reducing the matrix effect [16]. Recent configurations allow the use of compact and relatively portable equipment. It is also important to note that AAS allows mono-elemental analysis while TXRF can provide a simultaneous multi-elemental analysis. Moreover, calibration procedures are simpler with TXRF than with other multielemental techniques such as ICP-MS [17].

Acid digestion of solid materials is the usual procedure for sample pretreatment prior to trace element analysis. Ultrasonic slurry sampling (i.e., slurry sampling using ultrasonic devices for homogenization) has been successfully 
employed in a variety of applications along with AAS [18,19,20,21] and would allow a fast sample pretreatment for TXRF analysis without the use of concentrated acids at high temperature and pressure.

So far, the TXRF technique has been scarcely applied to sediment samples $[13,22,23,24,25]$ (Table 1), yet no work has appeared in the literature concerning slurry sampling for sediment analysis by this technique. Marguí et al. [26] used the direct analysis of slurries by TXRF for the determination of Se in soils. Slurry sampling is simpler, safer and faster than acid digestion. There is also a large difference in the sample size needed, $10 \mathrm{mg}$ in this study in contrast with the 100 $400[24,23]$ usually used in acid digestion, and hence, for those applications where the sample is limited, slurry sampling could be an attractive alternative.

This paper reports on a case study concerning the assessment of lithogenic, marine and anthropogenic trace elements in Ria of Arousa (Galicia, Spain) using a multielemental and portable TXRF equipment combined with ultrasonic-probe slurry sampling for sample pretreatment.

\section{MATERIAL AND METHODS}

\subsection{Reagents and standards.}

All chemicals were of analytical-reagent grade. Ultrapure water was obtained from A PETLAB system (Peter Taboada, Vigo, Spain). 69\% nitric acid $(\mathrm{m} / \mathrm{m})$ AnalaR Normapur (Prolabo, Fontenay-sous-Bois, France), Triton X-100 (Merck, Darmstadt, Germany) and germanium standard solution for AAS $996 \pm 4$ $\mathrm{mg} \mathrm{L}^{-1} \mathrm{Ge}$ (Sigma-Aldrich Chemie $\left.\mathrm{GmbH}\right)$, were used.

Acetone AnalR Normapur (Prolabo, Briare, France) and RBS $50^{\circledR}$ solution (Sigma-Aldrich, Steinheim, Germany) for cleaning the quartz sample carriers were 
also used. Silicon solution in isopropanol (Serva, Heidelberg, Germany) was used in order to make the surface of the quartz reflector hydrophobic and to prevent the spreading of the sample drop prior to TXRF analysis

The following certified reference materials were used for method validation: SRM 2702 Inorganics in marine sediments (National Institute of Standards \& Technology); PACS2 Marine Sediment Reference Materials for Trace Metals and other Constituents (National Research Council Canada); SRM 2710 Montana soil Highly Elevated Trace Element Concentrations (National Institute of Standards \& Technology) and SRM 2711 Montana soil Moderately Elevated Trace Element Concentrations (National Institute of Standards \& Technology).

\subsection{Instrumentation.}

Multielemental analysis was carried out with a portable Bruker S2 Picofox TXRF spectrometer (Bruker AXS Microanalysis GmbH, Berlin, Germany). The TXRF spectrometer is equipped with a Mo tube $(1000 \mu \mathrm{A}, 50 \mathrm{kV}, 50 \mathrm{~W})$, a multilayer monochromator and a silicon-drift detector with an active area of 10 $\mathrm{mm}^{2}$. The resolution of the detector was better than $160 \mathrm{eV}$ at $10 \mathrm{kcps}(\mathrm{Mn} \mathrm{Ka})$.

A Sartorius Micro $\mathrm{M}^{\mathrm{TM}}$ balance was employed for weighing samples. A Vibra-Cell ${ }^{\mathrm{TM}}$ ultrasonic processor model VC-50-1 (Sonics \& Materials Inc., Danbury CT, USA) (50 W power, $20 \mathrm{kHz}$ frequency) equipped with a $2 \mathrm{~mm}$ titanium probe was used for slurry mixing.

\subsection{Study area.}

The Ria of Arousa, located in the northwestern of the Iberian Peninsula (Fig. 1), is a V-shaped flooded valley with a sinuous littoral and secondary bays. 
This ria is the largest of the eighteen Galician rias with a surface area of $230 \mathrm{~km}^{2}$, $31 \mathrm{~km}$ long and a water content of $4.34 \mathrm{~km}^{3}$.

Freshwater contributions to Arousa are due to the Ulla and Umia rivers. The widest is the river Ulla, running into the ria head, with an annual average flow of $79.3 \mathrm{~m}^{3} \mathrm{~s}^{-1}$ and a drainage area of $2804 \mathrm{~km}^{2}$. So, the inner part of the ria is usually estuarine, whereas the outer part is mainly oceanic. The river Umia, with a basin of $440 \mathrm{~km}^{2}$, flows into the southern coast of the outer ria with a flow of $16.3 \mathrm{~m}^{3} \mathrm{~s}^{-1}$. The main fluvial drainage system, together with a set of small watersheds, constitutes the most important input of continental sediments that are eroded from plutonic (granites and granodiorites) and metamorphic rocks (gneisses) and their minerals [27]. Mud and sandy mud are the predominating type of sediments of ria bottom where the water circulation pattern governs the distribution of clay minerals. Two types of bioclasts debris are distinguished in the ria sediments, namely, lithothamnium and shell. The amount of those calcareous debris increases in direction to ocean [28].

Apart from the terrestrial origin of material to the sediment reservoir, there is another autochthonous source as result of falling of organic matter [4]. The Ria of Arousa is under the influence of strong seasonal upwelling events in the Galician coast [5]. The resulting high primary productivity in this ria, sheltered from strong surges, makes it especially suitable for mussel culture in rafts, the Ria of Arousa being the most productive one with $\approx 170,000 \mathrm{t}^{-1}$ of cultured mussel [2]. The mussels are filter feeders with a large capacity for excretion of dregs, which are accumulated under the raft polygons leading to an organic matter rich sludge. Evans et al. [29] indicated that metal concentrations in mussel fecal deposits tend to be higher than in the suspended particulate matter. However, Prego et al. [30] 
observed that the presence of metals in sediments of farming-free areas does not differ significantly from that found under the rafts in the Ria of Arousa.

Moreover, an anthropogenic input of metals to sediments occurs in this ria. River Ulla contributes with some metals that are trapped in the estuarine sediments [7]. Furthermore, the coast supports a dispersed population (326 inhab $\mathrm{km}^{-2}$ during summer it duplicates), which is engaged in activities related to tourism, agriculture, aquiculture, fishing and shell-fishing, like clams and cockle in the sallow and intertidal zone, mainly in the inner part of the ria and its bays. The main industry is canning, fresh and cold fish storage and sale in several fisheries ports as the Riberia and the maritime traffic of goods in the harbor of Vilagarcía-deArousa. Sewages are usually treated in plants along the shoreline.

\subsection{Sediment sampling}

Sediments of the Ria of Arousa were sampled from the R/V Mytilus and from its auxiliary boat "Zoea" in the shallow water zones. Surface sediments (first centimeter layer) were collected using two Shipeck grabs of $30 \mathrm{~L}$ and a $3.5 \mathrm{~L}$ capacity. Core sediments were taken in a PVC tube using a Gravity-Corer. Next, cores were sectioned longitudinally into two halves, and sub-samples of $1 \mathrm{~cm}$ thickness were separated. In the onshore laboratory of IIM-CSIC, sediment samples were dried slowly in an oven at $45 \pm 5^{\circ} \mathrm{C}$ and sieved through 2 and 0.063 $\mathrm{mm}$ sieves in a Retsch sifter. Then, sandy and mud fractions of Arousa samples were stored in polyethylene containers and kept in the sediment archive of Marine Biogeochemistry Research Group (IIM-CSIC). From this depository, 53 surface and 18 core samples (each core: $1 \mathrm{~cm}$ thickness at 40, 60, 80, 100, 120, 140, 180, 220 and $240 \mathrm{~cm}$ depths) of the fine fraction $(<0.063 \mathrm{~mm}$ sieve mesh) of sediment in the Ria of Arousa were taken. Locations of sampling points are shown in Fig. 1. 


\subsection{Analytical method}

Concentrations of ten elements ( $\mathrm{As}, \mathrm{Cu}, \mathrm{Fe}, \mathrm{Mn}, \mathrm{Pb}, \mathrm{Rb}, \mathrm{Sr}, \mathrm{Ti}, \mathrm{V}$ and $\mathrm{Zn}$ ) were determined in sediment samples of the Ria of Arousa by Total Reflection XRay Fluorescence (TXRF). A sample preparation procedure based on Ultrasonic Probe Slurry Sampling (UPSS) was developed as an alternative to the classical sample digestion method.

The analytical procedure was adapted from that proposed elsewhere for sample pretreatment prior to TXRF analysis $[31,32]$. It has been necessary to replace the usual internal standard, i.e. Ga, because it was found at a significant concentration in some sediment samples. There were several possibilities in the literature to replace $\mathrm{Ga}$, such as the use of $\mathrm{Co}[22]$, Ge $[26,33,34]$ Se [24] and $Y$ [35]. However, $\mathrm{Y}$ was detected like $\mathrm{Ga}$ at a significant concentration. The Co spectral signal was overlapped by the $\mathrm{K} \beta$ peak of $\mathrm{Fe}$ (very intense in all the studied samples) and is not easy to quantify. Ge has been shown to provide good results for soil analysis [26], and therefore, it was finally selected.

\subsection{Procedure}

A $10 \mathrm{mg}$ portion of sediment sample was accurately weighed on an analytical balance and placed in a $1.5 \mathrm{~mL}$ Eppendorf tube. Then, $1 \mathrm{~mL}$ of a surfactant solution was added to the tube. The surfactant consists of a $0.01 \% \mathrm{w} / \mathrm{v}$ Triton X-100 solution, $3 \% \mathrm{v} / \mathrm{v} \mathrm{HNO}_{3}$ and $1 \mathrm{mg} \mathrm{L}^{-1}$ of $\mathrm{Ge}$ as internal standard. Three replicates of each sample were performed.

The mixture was subjected to stirring by ultrasound for $30 \mathrm{~s}$ with an ultrasonic probe inserted directly into the sample vial. An aliquot of $10 \mu \mathrm{L}$ of the suspension was withdrawn immediately after stopping sonication. The aliquot was 
placed in the center of a Bruker quartz reflector $(30 \mathrm{~mm}$ diameter and $3 \mathrm{~mm}$ thickness), and dried gently on a hot plate until complete evaporation of the slurry diluent. The surface of the reflector was previously siliconized to make it hydrophobic using a silicon solution in isopropanol. Drops were maintained at a distance less than $5 \mathrm{~mm}$ from the center of the quartz reflector since this is the suitable area for detection.

Reflectors with the dried sample were introduced manually into the TXRF instrument. A lifetime (i.e., effective time of measurement) of $500 \mathrm{~s}$ was applied.

Spectra $^{\circledR}$ 6.2. Bruker AXS Mycroanalysis and PyMca 4.5.0. softwares were both employed in the treatment of TXRF spectra. Quantification was performed using a deconvolution based on a Bayesian inference (SuperBayes). IBM SPSS Statistics 19 was used for statistical analysis of data and Surfer 9 software was used to create isolines maps.

\subsection{Background metal levels and contamination degree of the ria sediments}

The determination of metal background concentrations (MBC) in order to evaluate the degree of contamination by metals in the Ria of Arousa was based on core clean-contaminated samples [36] instead of average crust earth content since the two cores sampled in Arousa take into account the local lithological characteristics.

Sediment normalization with respect to texture, using the fine fraction $(<63$ $\mu \mathrm{m})$ for all samples, and a conservative corrector element such as Fe were considered jointly, following the recommendations by Luoma et al. [37]. Metals are mainly accumulated in the fine fraction [38], which is, in addition, the fraction with 
suitable particle size for slurry sampling. On the other hand, Fe is an appropriate lithogenic normalizer since it is associated with fine particles [39], contamination does not vary its content [40], it is a major constituent that can be easily determined by TXRF and it has already been successfully used in contamination studies of rias [36].

In the Arousa cores, a linear relationship was calculated according to the eq. (1) based on metal concentration vs. Fe content at a depth $\geq 40 \mathrm{~cm}$ :

$$
\left[\mathrm{Me}^{\mathrm{Fe}}\right]=\mathrm{a} \cdot[\mathrm{Fe}]+\mathrm{b}
$$

where $\left[\mathrm{Me}^{\mathrm{Fe}}\right]$ provides the background concentration of the metal in relation to the concentration of $\mathrm{Fe}([\mathrm{Fe}])$ in the sample, "a" is the slope of the line and "b" is the intercept. Therefore, the Normalized Enrichment Factor (NEF) of each sample is given by its own metal background concentration, calculated from its Fe content to each element $\left(\left[\mathrm{Me}^{\mathrm{Fe}}\right]\right)$, as stated by the equation (2):

$$
\mathrm{NEF}=[\mathrm{Me}] /\left[\mathrm{Me}^{\mathrm{Fe}}\right]
$$

where $[\mathrm{Me}]$ is the metal content in the surface sediment sample and $\left[\mathrm{Me}^{\mathrm{Fe}}\right]$ is the MBC calculated by the normalization eq.(1).

Finally, the NEF criterion, which is indicative of sediment contamination, is based on the work by Hakanson [41] modified by Prego et al. [7] as follows:

$$
\text { Negligible }<1<\text { Possible }<2<\text { Moderate }<3<\text { Severe }<6<\text { Very severe }<9<
$$

\section{RESULTS AND DISCUSSION}

\subsection{Slurry optimization}


Several experimental parameters were studied in order to optimize the slurry procedure, namely, Triton X-100 concentration, sample mass employed (sample mass-to-volume ratio), sonication amplitude, sonication time and sedimentation time. Results are presented in Fig. 2 for four elements, i.e., $\mathrm{Mn}, \mathrm{Cu}$, $\mathrm{Rb}$ and $\mathrm{Pb}$.

\subsubsection{Slurry diluent and stabilizing agents}

Diluted $\mathrm{HNO}_{3}$ is the most used diluent because it increases the analyte extraction from the solid particles due to its oxidizing capability, helps the suspension stability and improves precision [42]. The concentration of $\mathrm{HNO}_{3}$ used in the literature is variable. As examples, Lima et al. [43] used a $0.5 \% \mathrm{v} / \mathrm{v}$ of $\mathrm{HNO}_{3}$ for analysis of river and marine sediments. A $3 \% \mathrm{v} / \mathrm{v} \mathrm{HNO}_{3}$ was selected in this study as slurry diluent following the recommendations given by Almeida-Pereira et al. [44] for analysis of marine sediments by ETAAS.

Stabilizing agents are not usually applied for slurry analysis of geological materials but they have proved useful [45] to avoid particle aggregation, to improve the slurry stability and to prevent problems in pippeting. Among the different stabilizing agents, e.g., ethanol, KO3006, glycerol and Triton X-100 [46], the latter has been extensively used as anionic surfactant for inorganic matrices [45].

Recovery results after testing different Triton X-100 concentrations $(0.001,0.01$, 0.1 and $1 \% \mathrm{v} / \mathrm{v}$ ) did not show any remarkable variation (shown in Fig. 2.A). However, as can be seen in Fig. 2.B, when the drop is deposited over the siliconized surface of the quartz reflector there is a relationship between the surfactant concentration and the drop diameter, the higher the surfactant 
concentration, the larger the drop diameter. Moreover, concentrations above $0.1 \%$ $\mathrm{v} / \mathrm{v}$ caused a non-homogeneous distribution of the sample material in the dried drop. Using a concentration lower than $0.001 \% \mathrm{v} / \mathrm{v}$, a drop size of $2.5 \mathrm{~mm}$ diameter was usually achieved. The drop size is a critical parameter in TXRF analysis, because the suitable area of detection is a circle from the centre of the reflector of $5 \mathrm{~mm}$ radius. With a concentration of $0.01 \% \mathrm{v} / \mathrm{v}$ Triton $\mathrm{X}-100$, the size drop had a radius of ca. $3.8 \mathrm{~mm}$.

\subsubsection{Particle size and sample mass}

The fine fraction of sediments $(<63 \mu \mathrm{m}$ mesh-size) was used to normalize with respect to texture. To avoid the necessity of sample grinding, maximum particle size was set as a goal in this study. Reference materials used in this work displayed a similar particle size (SRM $2702<70 \mu \mathrm{m}$; PACS2 $<125 \mu \mathrm{m}$; SRM 2710 and SRM $2711<74 \mu \mathrm{m})$.

Sample masses of $1,5,10$ and $15 \mathrm{mg}$ were tested. For a sample mass of 1 mg, aggregation was visually observed, giving rise to a non-homogeneous distribution of particles. As shown in Fig. 2C, a sample mass in the range of 5 to $10 \mathrm{mg}$ could be used since quantitative recoveries (i.e., 90-110\%) were observed for $\mathrm{Mn}, \mathrm{Fe}, \mathrm{Rb}$ and $\mathrm{Pb}$. Finally, a sample mass of $10 \mathrm{mg}$ was selected.

\subsubsection{Homogenization system}

Slurries were subjected to $10,20,30,40,50$ and $70 \%$ sonication amplitude for $30 \mathrm{~s}$. Samples submitted to $10 \%$ did not produce an homogeneous slurry and the dried samples were rejected to prevent damages in the detector because visually a thin layer was not formed. Slurries subjected to 50 and $70 \%$ sonication amplitude showed some foaming and splashing, especially at $70 \%$. More precise 
results were observed for samples sonicated at $30 \%$ amplitude (Fig. 2D), this amplitude being selected for further experiments.

Moreover, the sonication time was studied in the range 15-60 s (Fig. 2E). Recoveries near $100 \%$ were observed in all cases, but the most precise results were found at a sonication time of $30 \mathrm{~s}$, this time being selected for further experiments.

Finally, particle sedimentation was studied. For that purpose, sample aliquots were taken, approximately at a middle depth in the vial, just after stopping sonication and at 10, 30 and $60 \mathrm{~s}$ later (Fig. 2F). The most accurate and precise results were found when slurry aliquots are withdrawn just after stopping sonication. The high recovery found for some elements could be due to sedimentation process that increases the concentration of sample particles in the lower part of the vial where the aliquot was withdrawn. Therefore, it is more appropriate to withdraw the slurry aliquot immediately after stopping sonication.

\subsection{Method evaluation}

Method validation was performed by analyzing four Certified Reference Materials (CRM), two of which are marine sediment samples (SRM 2702 and PACS-2) and the other two are soil samples (SRM 2710 and SRM 2711). Three replicates of each were performed. A set of 22 elements was chosen for the study: From $\mathrm{Ca}(Z=20)$ to $\mathrm{Nb}(Z=41)$ and $\mathrm{Pb}(Z=82)$. Two criteria were used to verify the suitability of the method: (i) a non-statistically difference between the reference and the measured concentrations using a Student's t test for a statistical significance level of $95 \%$ and two degrees of freedom $(\alpha=0,05$ and $n=3)$ and (ii) 
a recovery in the range $80-120 \%$. A total of 10 elements fulfilled those criteria, i.e, Ti, V, Mn, Fe, Cu, Zn, As, Rb, Sr and Pb.

As an example, the distribution of elemental peaks in the spectra are shown in Fig. 3.

\subsection{Analytical characteristics}

Table 2 displays a summary of the analytical characteristics obtained for the analysis of CRMs, concentration intervals (lowest and highest concentration found in CRMs), the intervals of recoveries in the four CRMs, repeatability expressed as Relative Standard Deviation and limits of detection (LD) and quantification (LQ). Intervals arise from the analysis of four different reference materials since these characteristics depend strongly on the background signal so they are specific of each matrix. Results are expressed as the average value of three replicates. As can be noted, there were not significant differences between the experimental and certified concentration values (i.e., $t_{\exp }$ was lesser than $t_{\text {crit }}$ for a $95 \%$ confidence level, $n=3$, in a two-tailed Student's t distribution).

As a general rule, it is considered that an element can be detected if the peak area is statistically more than three times the background. It can be considered that one element can be quantified accurately, when the intensity of the peak exceeds 10 times the background level. Calculations were performed using the following expressions:

$$
\begin{aligned}
& L_{i}=\left(3 C_{i} \cdot \sqrt{ } N_{B G}\right) / N_{i} \\
& L Q_{i}=\left(10 C_{i} \cdot \sqrt{ } N_{B G}\right) / N_{i}
\end{aligned}
$$


Where $i$ is the analyte, $C_{i}$ is the concentration of the element $i, N_{B G}$ is the background level under de peak of the element $i$ and $N_{i}$ is the peak fluorescent area of the element i.

Quality control was performed by random introduction between samples of a single measurement of SRM 2702. Results were plotted as Shewhart graphs. In general, results felt within the lines set by the upper and lower warning levels (95 $\%$ confidence interval for a two tailed student's $t$ distribution, $n=3$ ), using the media and the standard deviation obtained in the previous analysis of the SRM 2702 as a reference (21 measurements). It can be concluded that the results remained reliable over time.

\subsection{Study in fieldwork.}

\subsubsection{Distribution and source of elements in the Ria of Arousa.}

Contents of ten elements analyzed were in the ranges of $10-32 \mathrm{mg} \mathrm{kg}^{-1} \mathrm{As}$, 7-105 mg kg-1 $\mathrm{Cu}, 12-40 \mathrm{~g} \mathrm{~kg}^{-1} \mathrm{Fe}, 97-474 \mathrm{mg} \mathrm{kg}^{-1} \mathrm{Mn}, 15-217 \mathrm{mg} \mathrm{kg}^{-1} \mathrm{~Pb}, 86$ $192 \mathrm{mg} \mathrm{kg}^{-1} \mathrm{Rb}, 88-880 \mathrm{mg} \mathrm{kg}^{-1} \mathrm{Sr}, 1.5-3.8 \mathrm{~g} \mathrm{~kg}^{-1} \mathrm{Ti}, 30-94 \mathrm{mg} \mathrm{kg}^{-1} \mathrm{~V}$ and 59-170 $\mathrm{mg} \mathrm{kg}^{-1} \mathrm{Zn}$. The distribution maps of these elements in the surface sediment of the Ria of Arousa are shown in Fig. 4. These results are in good agreement with those found in the literature, e.g., $\mathrm{Fe}, \mathrm{Cu}, \mathrm{Zn}$ and $\mathrm{Pb}$ analyzed in intertidal areas [47] and in the sedimentary biodeposits under mussel rafts zones $[30,48]$; $\mathrm{Pb}$ was also mapped and its contamination state determined [49].

Principal component analysis (PCA) was applied for searching the trace metal sources in the sediments of the Ria of Arousa. By applying PCA to a matrix of 9 features (total concentration of $\mathrm{Ti}, \mathrm{V}, \mathrm{Mn}, \mathrm{Cu}, \mathrm{Zn}, \mathrm{As}, \mathrm{Rb}, \mathrm{Sr}$ and $\mathrm{Pb}$ ) and 53 surface sediments, two components were extracted describing ca. $66 \%$ of the 
common variance. Orthogonal rotation method (Varimax) with Kaiser normalization was applied for better interpretation. Fe was removed from the variables to avoid its influence in the variance of the other elements studied. The loading plot of component 1 vs. component 2 is shown in Fig. 5 . The component 1 accounts for a $53 \%$ of the common variance and is highly loaded by $\mathrm{Ti}, \mathrm{Mn}, \mathrm{Rb}$ and Sr. The negative loading of Sr suggests an antagonistic behaviour in respect to $\mathrm{Ti}, \mathrm{Mn}$ and $\mathrm{Rb}$. The component 2 describes a $13 \%$ of the total variance of the data, is highly loaded by $\mathrm{Cu}, \mathrm{Zn}, \mathrm{As}$ and $\mathrm{Pb}$. Component 1 can be defined as the natural (continental plus marine) source of elements whereas component 2 is related to an anthropogenic input.

Four different patterns can be observed both in the distribution maps and the PCA analysis. Elements can be classified according to their origin as follows:

(A) Lithogenic-continental elements. The first distribution group includes $\mathrm{Mn}, \mathrm{Rb}, \mathrm{Ti}, \mathrm{V}$ and $\mathrm{Fe}$ (not included in the PCA). In the PCA analysis, the component 1 is positive loaded by those elements, all them with factor loadings higher than 0.6. They displayed the highest contents in the sediments near the estuarine zone close to the mouths of Ulla and Umia rivers and northward littoral of the ria. Ti displays its maximum values near shores and estuaries, which can be attributed to continental origin from coastal lithogenic sources. Unlike the other four elements, Mn exhibited a maximum content at the Umia mouth. Mn content increased towards the estuarine zones in the Ria of Arousa, its highest content being in the Ulla $[50,51]$ and Umia [47] estuaries, thereby reflecting the continental origin [9]. $\mathrm{V}$ and $\mathrm{Rb}$, have been scarcely studied in other rias, (e.g., Ria of Vigo). Thus $V$ [7] showed similar contents in both rias and no contamination was suspected. A lithogenic-continental origin can be attributed to these elements. 
(B) Biogenic-marine elements. A second group containing only Sr shows concentrations increasing seaward and in the shores of the oceanic ria part. Its ria distribution is similar to biogenic carbonates, like in other rias [52]. As a consequence of its similarity between $\mathrm{Ca}$ and $\mathrm{Sr}$, the latter can replace $\mathrm{Ca}$ in carbonates and accumulate in shells. In the PCA analysis, Sr is highly negative loading the component 1 . Sr can be related to a biogenic autochthonous origin.

(C) Anthropogenic elements. This group includes only $\mathrm{Pb}$. Its sedimentary content is relatively homogeneous in the whole ria, being disturbed by two small higher-concentration zones, one in the vicinity of the Vilagarcía Harbor and another near to the sallow fishing boats port of Cambados. The low loading, close to zero in the component 1 , suggests neither lithogenic nor biogenic origin. However, component 2 is highly loaded by $\mathrm{Pb}$. Barciela-Alonso et al. [49] observed a moderate to considerable contamination by $\mathrm{Pb}$ near the Vilagarcía Harbor and areas with an intense ship traffic, so component 2 could be related to an anthropogenic origin.

(D) Lithogenic-anthropogenic elements. This group includes $\mathrm{Cu}, \mathrm{Zn}$ and $\mathrm{As}$. Similarly to the group (A), they showed higher contents in sediments toward the river mouth areas, but their metal contents decrease seaward. In the PCA analysis, the three elements jointly with $\mathrm{Pb}$ are highly loading component 2 . Nevertheless, the difference with $\mathrm{Pb}$ is their remarkable contribution to component 1. In the loading plot (Fig. 5), they are between $\mathrm{Ti}$ (lithogenic) and $\mathrm{Pb}$ (anthropogenic) suggesting that both sources are influencing their distribution. Higher Cu concentrations close to the Umia and the Ulla estuaries (Fig. 4) should be of fluvial origin. Prego et al. [30] indicated that the Ulla River is an important 
source of metals such as $\mathrm{Cu}$, due to the occurrence of an ancient chalcopyrite mine in its catchment. $\mathrm{Zn}$ and As show a similar distribution.

\subsubsection{Assessment of the contamination degree in the ria.}

Is the ria contaminated? To answer this question it is necessary to determine the natural concentration levels. The background content $\left(\mathrm{mg} \mathrm{kg}^{-1}\right)$ for each element in sediments was defined as a function of the Fe content $\left(\mathrm{g} \mathrm{kg}^{-1}\right)$ in the preindustrial layer (> $40 \mathrm{~cm}$ depth) of two sediment cores. Fig. 6 displays the normalization graphs for $\mathrm{Zn}, \mathrm{As}, \mathrm{Rb}$ and Sr. Results are shown in the following element-Fe equations:

$$
\begin{aligned}
& {\left[\mathrm{Ti}^{\mathrm{Fe}}\right]=77.5 \cdot[\mathrm{Fe}]+31.7 \quad(\mathrm{R}=0.96)} \\
& {\left[\mathrm{V}^{\mathrm{Fe}}\right]=1.87 \cdot[\mathrm{Fe}]+7.3 \quad(\mathrm{R}=0.78)} \\
& {\left[\mathrm{Mn}^{\mathrm{Fe}}\right]=4.95 \cdot[\mathrm{Fe}]+25.1 \quad(\mathrm{R}=0.75)} \\
& {\left[\mathrm{Cu}^{\mathrm{Fe}}\right]=0.491 \cdot[\mathrm{Fe}]+3.5 \quad(\mathrm{R}=0.79)} \\
& {\left[\mathrm{Zn}^{\mathrm{Fe}}\right]=2.21 \cdot[\mathrm{Fe}]+6.2 \quad(\mathrm{R}=0.95)} \\
& {\left[\mathrm{As}^{\mathrm{Fe}}\right]=1.01 \cdot[\mathrm{Fe}]-10.8 \quad(\mathrm{R}=0.97)} \\
& {\left[\mathrm{Rb}^{\mathrm{Fe}}\right]=4.02 \cdot[\mathrm{Fe}]+11.6 \quad(\mathrm{R}=0.94)} \\
& {\left[\mathrm{Sr}^{\mathrm{Fe}}\right]=782-11.9 \cdot[\mathrm{Fe}] \quad(\mathrm{R}=0.76)} \\
& {\left[\mathrm{Pb}^{\mathrm{Fe}}\right]=0.729 \cdot[\mathrm{Fe}]-2.0 \quad(\mathrm{R}=0.92)}
\end{aligned}
$$

NEFs were calculated as $\left([\mathrm{Me}] /\left[\mathrm{Me}^{\mathrm{Fe}}\right]\right)$ [eq. (2)]. Most of the considered elements, e.g., Ti, V, Mn, $\mathrm{Zn}, \mathrm{Rb}$ and $\mathrm{Sr}$, exhibited enrichment factors that did not exceed the value of 2, i.e., natural or near-natural levels in the sediment. However, a contamination of the ria sediments was detected in the case of $\mathrm{Cu}$, As and $\mathrm{Pb}$ since these elements showed normalized enrichment factors above 3 (mapped in 
Fig. 7). The data points of $\mathrm{Zn}, \mathrm{Cu}$ and As cluster together in the PCA analysis, hence meaning a similar source. Nevertheless, NEFs greater than three where not found for $\mathrm{Zn}$. For $\mathrm{Cu}$, severe contamination was observed close to the Ulla and Umia River mouths and Vilagarcia Harbor. For As, severe contamination was focused on the Cambados shoreline. Finally, $\mathrm{Pb}$ contamination occurred in the southern margin of the ria including small areas with a very severe contamination. Local areas with severe contamination of surface sediments occur for those elements, yet a different spatial distribution is observed for each one.

\section{CONCLUSIONS}

The UPSS-TXRF technique allows a successful determination of ten metals in coastal sediments, i.e., Ti, V, Mn, Fe, Cu, Zn, As, Rb, $\mathrm{Sr}$ and Pb. These metals were determined simultaneously without digesting the sample and with a minimum expenditure of reagents. Analysis time for each sample (three replicates per sample) was $30 \mathrm{~min}$, including weighing, slurry preparation, measurement and interpretation of the obtained spectra.

It is possible to distinguish three different main sources of elements in the Ria of Arousa: (i) autochthonous (Sr) from biogenic processes in the ria like calcareous shells sink, (ii) allochtonous from continental inputs thought river flows ( $\mathrm{V}, \mathrm{Mn}, \mathrm{Rb}$ and $\mathrm{Ti})$, associated to the geochemical composition of the river basins, and (iii) anthropogenic influence ( $\mathrm{Pb}, \mathrm{Cu}, \mathrm{Zn}, \mathrm{As})$ sources.

Specific contamination due to $\mathrm{Pb}, \mathrm{Cu}$ and As was identified, most important areas with anthropogenic enrichment being the fluvial mouths and the southern ria 
shore. $\mathrm{Pb}$ contamination was observed specially located in areas with intense shipping activity.

Acknowledgements. Authors thank the crew of the R/V Mytilus for their help during the surveys. Financial support by Spanish Ministry of 'Economy and Competitiveness' through the projects CTM2011-28792-C02, CTQ2009-06956 and CTQ2012-32788 is gratefully acknowledged. M.A. Alvarez-Vazquez thanks the University of Vigo for a grant.

\section{References}

[1] G. Evans, R. Prego, Rias, estuaries and incised valleys: is a ria an estuary?, Mar. Geol. 196 (2003) 171-175

[2] F.G. Figueiras, U. Labarta, M.J. Reiriz, Coastal upwelling, primary production and mussel growth in the Rias Baixas of Galicia, Hydrobiologia 484 (2002) 121-131.

[3] M. Varela, R. Prego, Y. Pazos, A. Moroño, Influence of upwelling and river runoff interaction of phytoplankton assemblages in a Middle Galician Ria ans comparison with northern and southern rias (NW Iberian Peninsula), Estuar Coast Shelf Sci 64 (2005) 721-737.

[4] G. Evans, R. Prego, J.E. Marshall, Organic matter in ria sediments: relevance of terrestrial sources and temporal variations in rates of accumulation. Estuar Coast Shelf Sci 94 (2011) 246-254.

[5] F. Fraga, Upwelling of the Galician coast, Northwest Spain, in: F.A. Richards (Ed.), Coastal upweling, American Geophysical Union, Washington, 1981, pp. 176-182.

[6] R. Prego, R. Bao, Upwelling influence on the Galicia coast: silicate in shelf water and underlying surface sediments, Cont Shelf Res 17 (1997) 307-318.

[7] R. Prego, P. Ferro, C. Trujillo, Lead and Zinc contamination of surface sediments in the main harbors of the Galician Rias, J. iber. geol. 34 (2008) 243-252.

[8] A. García, P. Bernárdez, R. Prego, Copper in Galician ria sediments: natural levels and contamination. Sci. Mar. 77S1 (2013) 91-99. 
[9] R. Prego, A. Cobelo-García, Twentieth century overview of heavy metals in the Galician Rias (NW Iberian Peninsula), Environ Pollut 121 (2003) 425-452.

[10] U. Förstner, Sediment-associated contaminants. An overview of basis for developing remedial options, Hydrologia 149 (1987) 221-246.

[11] W. Salomons, H. Kerdijk, H.Y. Van Pagee, A. Schreur, Behaviour and impact assessment of heavy metals in estuarine and coastal zones, in: U. Seeliger, L.D. de Lacerda, S.D. Patchineelam, (Eds.), Metals in Coastal Environments of Latin America. Springer-Verlag, Berlin, 1985, pp. 157-198.

[12] B. Welz, M. Sperling, Atomic absorption spectrometry, 3rd ed. Wiley-VCH, Weinheim, 1999.

[13] T. Gasparics, I. Csató, Gy. Záray, Analysis of Antartic Marine Sediment by Inductively Coupled Plasma Atomic Emission and Total Reflection X-Ray Fluorescence Spectrometry, Microchem J 55 (1997) 56-63.

[14] H. Papaefthymiou, G. Papatheodorou, A comparison between INAA and ICP-MS for the determination of element concentrations in marine sediments, J Radional Nucl Chem 289 (2011) 679-688.

[15] P. Wobrauschek, Total Reflection x-ray fluorescence analysis - a review. X Ray Spectrom 36 (2007) 289-300.

[16] H. Aiginger, Historical development and principles of total reflection X-ray fluorescence analysis (TXRF). Spectrochim Acta Part B At Spectrosc 46(10) (1991) 1313-1321.

[17] R. Pepelnik, A. Prange, R. Niedergesäß, Comparative Study of Multi-element Determination Using Inductively Coupled Plasma Mass Spectrometry, Total Reflection X-ray Fluorescence Spectrometry and Neutron Activation Analysis. J Anal At Spectrom 9 (1994) 1071-1074.

[18] C. Bendicho, I. de La Calle, F. Pena, M. Costas, N. Cabaleiro, I. Lavilla, Ultrasound-assisted pretreatment of solid samples in the context of green analytical chemistry, Trends Analyt Chem 31 (2012) 50-60.

[19] C. Santos, F. Alava-Moreno, I. Lavilla, C. Bendicho, Total As in seafood as determined by transverse heated electrothermal atomic absorption spectrometry-longitudinal Zeeman background correction: an evaluation of automated ultrasonic slurry sampling, ultrasound- 
assisted extraction and microwave-assisted digestion methods, J Anal At Spectrom 15 (2000) 987-994.

[20] H. Méndez, F. Alava, I. Lavilla, C. Bendicho, Determination of selenium in marine biological tissues by transverse heated electrothermal atomic absorption spectrometry with longitudinal Zeeman background correction and automated ultrasonic slurry sampling, J AOAC Int 84 (2001) 1921-1926.

[21] L. Amoedo, J.L. Capelo, I. Lavilla, C. Bendicho, Evaluation of Platanus occidentalis and Pinus sylvestris as bioindicators for lead and cádmium by slurry sampling-electrothermal atomic absorption spectrometry, J AOAC Int 85 (2002) 212-218.

[22] C. Koopmann, A. Prange, Multielemental determination in sediments from the German Wadden Sea - investigations on sample preparation techniques. Spectrochim Acta Part B At Spectrosc 46(10) (1991) 1395-1402.

[23] G.A. Battiston, R. Gerbasi, S. Degetto, G. Sbrignadello, Heavy metal speciation in coastal sediments using total-reflection X-ray fluorescence spectrometry. Spectrochim Acta Part B At Spectrosc 48(2) (1993) 217-221.

[24] H. Miesbauer, Multielement determination in sediments, pore wáter and river wáter of Upper Austrian rivers by total-reflection X-ray fluorescence, Spectrochim Acta Part B At Spectrosc 52(7) (1997) 1003-1007.

[25] M.M. Costa, M.A. Barreiros, M.L. Carvalho, I. Queralt, Multi-Element Characterization of Estuarine Sediments and Waters. X Ray Spectrom 28 (1999) 410-413.

[26] E. Marguí, G.H. Floor, M. Hidalgo, P. Kregsamer, G. Román-Ross, C. Streli, I. Queralt, Analytical Possibilities of Total Reflection X-ray Spectrometry (TXRF) for Trace Selenium Determination in Soils. Anal. Chem. 82(18) (2010) 7744-7751.

[27] P. Floor, Basement rocks of western Galicia as sources for the minerals in the Ria de Arosa. Leidse Geologische Mededelingen 37 (1968) 69-76.

[28] W.S. Koldijk, Bottom sediments of the Ria de Arosa (Galicia, NW Sapin), Leidse Geologische Mededelingen 37 (1968) 77-134.

[29] G. Evans, R.J. Howarth, M.A. Nombela, Metals in the sediments of Ensenada de San Simón (inner Ria de Vigo), Galicia, NW Spain. Appl Geochem 18 (2003) 973-996. 
[30] R. Prego, U. Otxotorena, A. Cobelo-García, Presence of $\mathrm{Cr}, \mathrm{Cu}, \mathrm{Fe}$ and $\mathrm{Pb}$ in sediments underlying mussel-culture rafts (Arosa and Vigo rias, NW Spain) Are they metalcontaminated areas?. Cienc Mar 32(2B) (2006) 339-349.

[31] I. de la Calle, N. Cabaleiro, I. Lavilla, C. Bendicho, Ultrasound-assisted single extraction tests for rapid assessment of metal extractability from soils by total reflection X-ray fluorescence. J. Hazard. Mater. 260 (2013) 202-209.

[32] I. de la Calle, M. Costas, N. Cabaleiro, I. Lavilla, C. Bendicho, Use of high-intensity sonication for pre-treatment of biological tissues prior to multielemental analysis by total reflection $\mathrm{X}$ ray fluorescence spectrometry. Spectrochim Acta Part B At Spectrosc 67 (2012) 43-49.

[33] A. von Bohlen, R. Eller, R. Klockenkämper, G. Tölg, Microanalysis of Solid Samples by TotalReflection X-ray Fluorescence Spectrometry. Anal Chem 59(21) (1987) 2551-2555.

[34] R. Klockenkämper, A. von Bohlen, Survey of sampling techniques for solids suitable for microanalysis by total-reflection X- ray fluorescence spectrometry. J Anal At Spectrom 14 (1999) 571-576.

[35] R. Klockenkämper, Total-Reflection X-Ray Fluorescence Analysis, John Wiley \& Sons, INC. New York, 1997.

[36] A. Cobelo-García, R. Prego, Heavy metal sedimentar record in a Calician Ria (NW Spain): background values and recente contamination. Mar. Pollut. Bull. 46 (2003) 1253-1262.

[37] S.N. Luoma, R. Dagovitz, E. Axtaman, Temporally intensive study of trace metals in sediments and bivalves from a large riverstuarine system: Suisun Bay/Delta in San Francisco Bay. Sci. Total Environ. 97 (1990) 685-712.

[38] P.J. Hanson, D.W. Evans, D.R. Colby, Assessment of elemental contamination in estuarine and coastal environments based on geochemical and statistical modeling of sediments. Mar. Environ. Res. 36 (1993) 237-266.

[39] D.H. Loring, Normalization of heavy-metal data from estuarine and coastal sediments. ICES J. Mar. Sci. 48 (1991) 101-115.

[40] F. Ackerman, A procedure for correcting the grain size effect in heavy metal analyses of estuarine and coastal sediments. Environ Technol 1(11) (1980) 518-527.

[41] L. Hakanson, An ecological risk index for aquatic pollution control. A sedimentological approach. Water Res. 14 (1980) 975-1001. 
[42] C. Bendicho, M.T.C de Loos-Vollebregt,. Solid Sampling in Electrothermal Atomic Absoption Spectrometry Using Commercial Atomizers. A Review. J Anal At Spectrom 6(5) (1991) 353-374.

[43] E.C. Lima, F.; Barbosa, F.J. Krug, M.M. Silva, M.G.R. Vale, Comparison of ultrasoundassisted extraction, slurry sampling and microwave-assisted digestion for cadmium, copper and lead determination in biological and sediment samples by electrothermal atomic absorption spectrometry. J Anal At Spectrom. 15(8) (2000) 995-1000.

[44] L. Almeida Pereira, I. Amorim, J.B. Borba da Silva, Determination of cadmium, chromium and lead in marine sediment slurry samples by electrothermal atomic absorption spectrometry using permanent modifiers. Talanta 68 (2006) 771-775.

[45] M.J. Cal-Prieto, M. Felipe-Sotelo, A. Carlosena, J.M. Andrade, P. López-Mahía, S. Muniategui, D. Prada, Slurry sampling for direct analysis of solid materials by electrothermal atomic absorption spectrometry (ETAAS). A literature review from 1990 to 2000. Talanta 56 (2002) 1-51.

[46] S.L. Costa Ferreira, M. Miró, E.G. Paranhos da Silva, G. Domingues Matos, P. Sanches dos Reis, G. Cardoso Brandao, W.N. Lopes dos Santos, A. Tavares Duarte, M.G. Rodriguez Vale, R.G. Oliveira Araujo, Slurry Sampling - An Analytical Strategy for the Determination of Metals and Metalloids by Spectroanalytical Techniques. Appl. Spectrosc. Rev. 45 (2010) 44-62.

[47] A. Carballeira, E. Carral, X. Puente, R. Villares, Regional-scale monitoring of coastal contamination. Nutrients and heavy metals in estuarine sediments and organisms on the coast of Galicia (northwest Spain). Int. J. Environ. Pollut. 13 (2000) 534-572.

[48] X.L. Otero, R.M. Vidal-Torrado, R.M. Calvo de Anta, F. Macías, Trace elements in biodeposits and sediments from mussel culture in the Ría de Arousa (Galicia, NW Spain). Environ. Pollut. 136 (2005) 119-134.

[49] M.C. Barciela-Alonso, P. Pazos-Capeáns, M.E. Regueira-Miguens, A. Bermejo-Barrera, P. Bermejo-Barrera, Study of cadmium, lead and tin distribution in surface marine sediment samples from Ria de Arousa (NW of Spain). Anal. Chim. Acta 524 (2004) 115-120.

[50] M.J. Belzunce Segarra, E. Helios-Rybicka, R. Prego, Distribution of heavy metals in the river Ulla and its estuary (North-west Spain). Oceanological Studies 26(2-3) (1997) 139-152. 
[51] R. Prego, M.J. Belzunce, E. Helios-Rybicka, M.C. Barciela, Cadmium, manganese, nickel and lead contents in surface sediments of the lower Ulla River and its estuary (northwest Spain). Boletín Instituto Español Oceanografía, 15(1-4) (1999) 495-500.

[52] B. Rubio, M.A. Nombela, F. Vilas, Geochemistry of major and trace elements in sediments of the Ria de Vigo (NW Spain): an assessment of metal pollution. Mar. Pollut. Bull. 40 (2000) 968-980. 
Table 1. Summary of sediment analysis by TXRF in the literature. There was no reference to direct analysis of samples by forming slurries.

\begin{tabular}{|c|c|c|c|c|c|c|c|c|}
\hline Sediment & $\begin{array}{l}\text { Fraction } \\
(\mu \mathrm{m})\end{array}$ & $\begin{array}{l}\text { Weigh of } \\
\text { sample } \\
\text { (mg) }\end{array}$ & Digestion & $\begin{array}{l}\text { Determined } \\
\text { elements }\end{array}$ & Cathode & $\begin{array}{l}\text { Live } \\
\text { time (s) }\end{array}$ & $\begin{array}{l}\text { Internal } \\
\text { standard }\end{array}$ & Ref. \\
\hline Marine & $<20$ & $100-250$ & $\begin{array}{c}\mathrm{AD}\left(\mathrm{HNO}_{3}\right) \\
\mathrm{MAD}\left(\mathrm{HF}+\mathrm{HNO}_{3}\right)\end{array}$ & $\begin{array}{c}\mathrm{K}^{1}, \mathrm{Ca}^{1}, \mathrm{Fe}, \mathrm{Ti}^{1}, \mathrm{~V}^{1}, \\
\mathrm{Cr}, \mathrm{Mn}^{1}, \mathrm{Ni}, \mathrm{Cu}, \mathrm{Zn}, \\
\mathrm{Ga}^{1}, \mathrm{As}, \mathrm{Rb}^{1}, \mathrm{Sr}^{1}, \mathrm{Y}^{1}, \\
\mathrm{~Pb}\end{array}$ & Mo \& W & 3000 & Co & [22] \\
\hline Marine & total & 400 & $\begin{array}{c}\text { SE } \\
\text { (totals provided) }\end{array}$ & $\begin{array}{l}\mathrm{K}^{1}, \mathrm{Ca}^{1}, \mathrm{Ti}^{1}, \mathrm{Mn}^{1} \\
\mathrm{Fe}^{1}, \mathrm{Ba}^{1}, \mathrm{Rb}^{1}, \mathrm{Cr}^{1} \\
\mathrm{Cu}^{1}, \mathrm{Sr}^{1}, \mathrm{Zn}^{1}, \mathrm{~Pb}^{1}\end{array}$ & Mo \& W & 500 & Co & [23] \\
\hline Marine & total & 100 & $\mathrm{MAD}\left(\mathrm{HNO}_{3}\right)$ & $\begin{array}{l}\mathrm{Fe}, \mathrm{Mn}^{2}, \mathrm{Zn}, \mathrm{Cr}^{2} \\
\mathrm{Cu}, \mathrm{Pb}, \mathrm{Ni}, \mathrm{Sn}^{2}, \mathrm{As}\end{array}$ & Mo \& W & 1000 & $\mathrm{Se}$ & [13] \\
\hline Fluvial & $<40$ & 100 & $\mathrm{AD}\left(\mathrm{HF}+\mathrm{HNO}_{3}\right)$ & $\begin{array}{c}\mathrm{S}, \mathrm{K}, \mathrm{Ca}, \mathrm{Ti}, \mathrm{V}, \mathrm{Cr} \\
\mathrm{Mn}, \mathrm{Fe}, \mathrm{Ni}, \mathrm{Cu}, \mathrm{Zn}, \\
\mathrm{As}, \mathrm{Sr}, \mathrm{Pb}, \mathrm{Sn}, \mathrm{Sb} \\
\mathrm{Mo}\end{array}$ & Mo \& W & 2000 & $\mathrm{Se}$ & [24] \\
\hline Estuarine & $<63$ & 200 & $\begin{array}{c}\mathrm{AD} / \mathrm{MAD} \\
\left(\mathrm{HF}+\mathrm{HNO}_{3}+\mathrm{H}_{2} \mathrm{O}_{2}\right)\end{array}$ & $\begin{array}{c}\mathrm{Cr}, \mathrm{Mn}^{1}, \mathrm{Fe}^{1}, \mathrm{Ni}, \mathrm{Cu} \\
\mathrm{Zn}, \mathrm{As}, \mathrm{Sr}^{1}, \mathrm{Zr}^{1}, \mathrm{Cd} \\
\mathrm{Pb}\end{array}$ & Mo \& W & n.a.d. & $\mathrm{Ga}$ & [25] \\
\hline Ria & $<63$ & 10 & UPSS & $\begin{array}{l}\mathrm{Ti}, \mathrm{V}, \mathrm{Mn}, \mathrm{Fe}, \mathrm{Cu} \\
\mathrm{Zn}, \mathrm{As}, \mathrm{Rb}, \mathrm{Sr}, \mathrm{Pb}\end{array}$ & Mo & 500 & $\mathrm{Ge}$ & $\begin{array}{l}\text { This } \\
\text { study }\end{array}$ \\
\hline
\end{tabular}

AD (acid digestion), MAD (microwave assisted digestion), SE (sequential extraction), UPSS (ultrasound probe slurry sampling), n.a.d. (not available data)

${ }^{1}$ Verification with sediment standard material not presented; ${ }^{2}$ Recovery under $80 \%$ or over $120 \%$. 
Table 2. Experimental results obtained to each chemical element from the evaluation method: concentration ranges in the reference materials, percentage of recovery, relative standard deviation (RSD), limits of detection (LD) and quantization (LQ), and Student's test (tabulated $t$ value for $n=3$ and $\alpha=0.05$ is 4.303 ). * Not certified value.

\begin{tabular}{cccccccccc}
\hline Element & $\begin{array}{c}\text { Range } \\
\left(\mathrm{mg} \cdot \mathrm{kg}^{-1}\right)\end{array}$ & $\begin{array}{c}\text { Recovery } \\
(\%)\end{array}$ & $\begin{array}{c}\text { RSD } \\
(\%)\end{array}$ & $\begin{array}{c}\mathrm{LD} \\
\left(\mathrm{mg}^{\mathrm{k}} \mathrm{kg}^{-1}\right)\end{array}$ & $\begin{array}{c}\text { LQ } \\
\left(\mathrm{mg} \cdot \mathrm{kg}^{-1}\right)\end{array}$ & SRM 2702 & PACS-2 & SRM 2711 & SRM 2710 \\
\hline $\mathrm{Ti}$ & $250-880$ & $84-101$ & $14-29$ & $13-23$ & $44-78$ & 1.65 & 1.52 & 0.06 & 1.81 \\
$\mathrm{~V}$ & $77-358$ & $86-95$ & $13-42$ & $13-21$ & $44-69$ & 1.65 & 0.96 & 0.23 & 0.38 \\
$\mathrm{Mn}$ & $638-10100$ & $79-98$ & $5-20$ & $11-19$ & $38-64$ & 0.70 & 2.36 & 0.28 & 3.46 \\
$\mathrm{Fe}$ & $2890-7910$ & $88-112$ & $7-16$ & $7-8$ & $22-27$ & 0.42 & 1.73 & 1.16 & 1.36 \\
$\mathrm{Cu}$ & $114-2950$ & $88-98$ & $8-17$ & $2-4$ & $7-14$ & 0.41 & 2.89 & 2.51 & 0.30 \\
$\mathrm{Zn}$ & $350-6950$ & $90-105$ & $8-17$ & $2-4$ & $6-15$ & 0.31 & 2.07 & 0.90 & 1.82 \\
$\mathrm{As}$ & $26-626$ & $100-111$ & $9-11$ & $1-3$ & $4-9$ & 1.38 & 0.02 & 0.71 & 2.08 \\
$\mathrm{Rb}$ & $110-128$ & $100-125 *$ & $6-21$ & $1-2$ & $4-7$ & 0.59 & -- & 2.30 & 0.05 \\
$\mathrm{Sr}$ & $120-330$ & $84-105$ & $9-30$ & $1-2$ & $5-6$ & 3.22 & 1.11 & 0.47 & 2.53 \\
$\mathrm{~Pb}$ & $133-5530$ & $86-112$ & $6-23$ & $2-3$ & $5-11$ & 0.11 & 3.37 & 3.07 & 0.06 \\
\hline
\end{tabular}




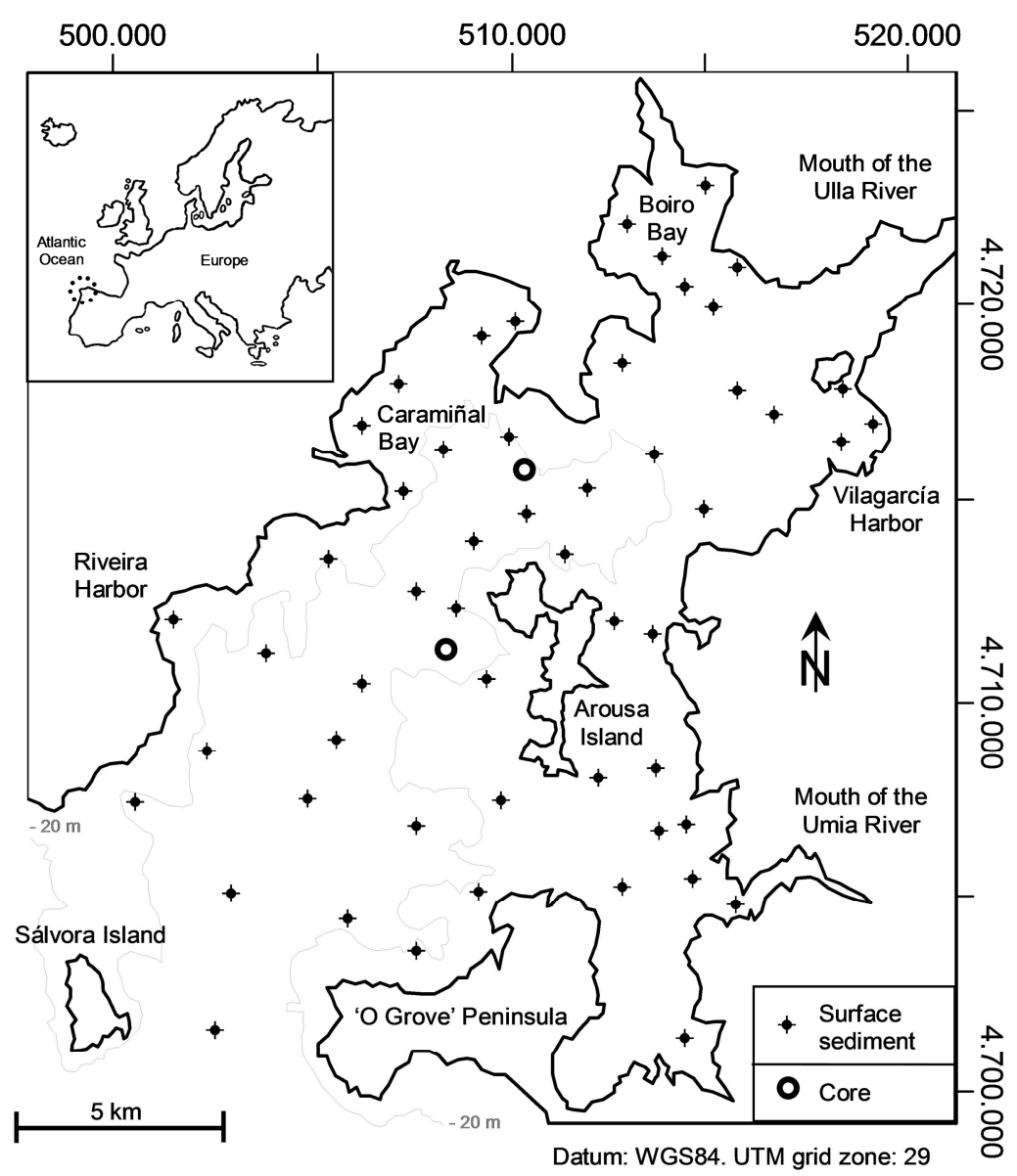

Figure 1. Map of the Ría of Arousa with the surface sediment and core sampling stations and main geographical accidents. 

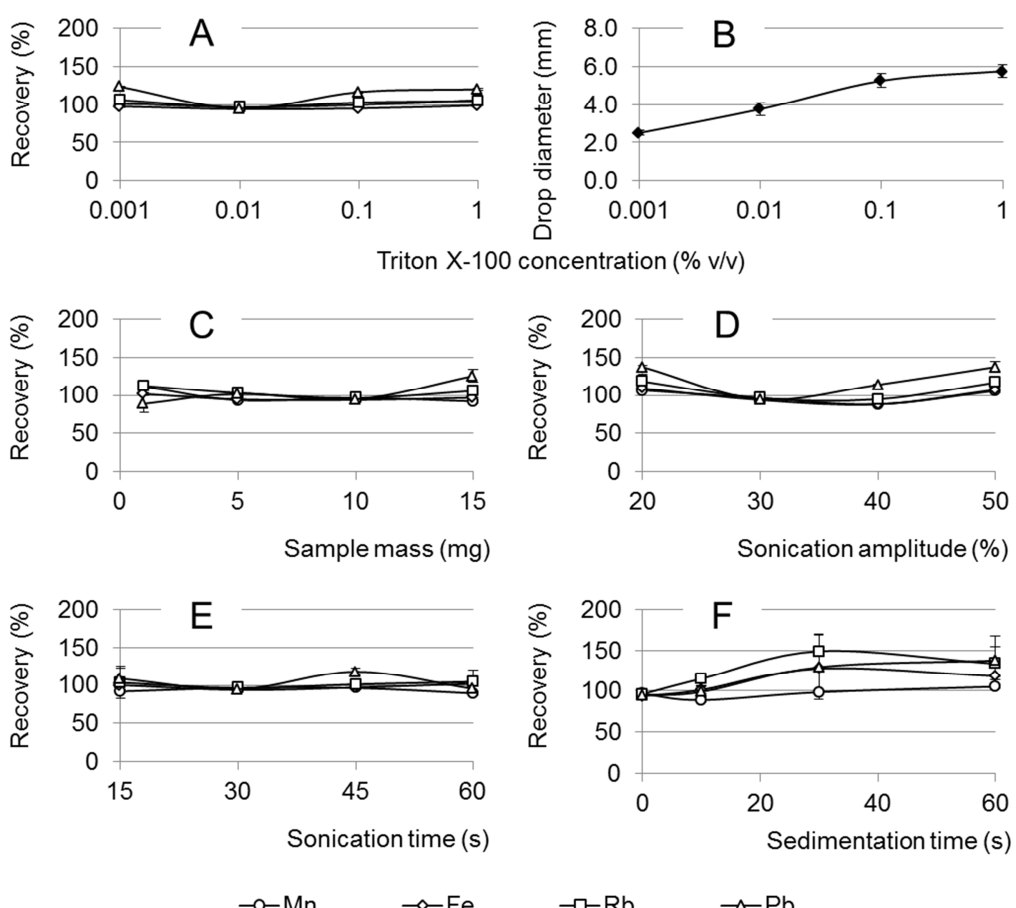

Figure 2. Optimization curves of slurry sampling procedure. A) Study of the Triton X-100 concentration. The rest of the parameters were fixed at $10 \mathrm{mg}$ of sample mass, $30 \mathrm{~s}$ sonication time at $30 \%$ amplitude and $0 \mathrm{~s}$ of sedimentation time. B) Drop size (diameter in $\mathrm{mm}$ ) after drying depending on the Triton X-100 concentration. C) Study of the sample mass or relationship sample mass-volume. The rest of the parameter were fixed at $0.01 \% \mathrm{v} / \mathrm{v}$ Triton X-100, $30 \mathrm{~s}$ sonication time at $30 \%$ amplitude and $0 \mathrm{~s}$ of sedimentation time. D) Study of the sonication amplitude. The rest of parameters were fixed at $0.01 \% \mathrm{v} / \mathrm{v}$ Triton X-100, $10 \mathrm{mg}$ sample mass, $30 \mathrm{~s}$ sonication time and 0 $s$ of sedimentation time. E) Study of sonication time. The rest of the parameters were fixed at 0.01 $\% \mathrm{v} / \mathrm{v}$ Triton $\mathrm{X}-100,10 \mathrm{mg}$ sample mass, sonication at $30 \%$ amplitude and $0 \mathrm{~s}$ of sedimentation time. F) Study of sedimentation time. The rest of the parameters were fixed at $0.01 \% \mathrm{v} / \mathrm{v}$ Triton X$100,10 \mathrm{mg}$ of sample mass and 30 s sonication time at $30 \%$ amplitude. 


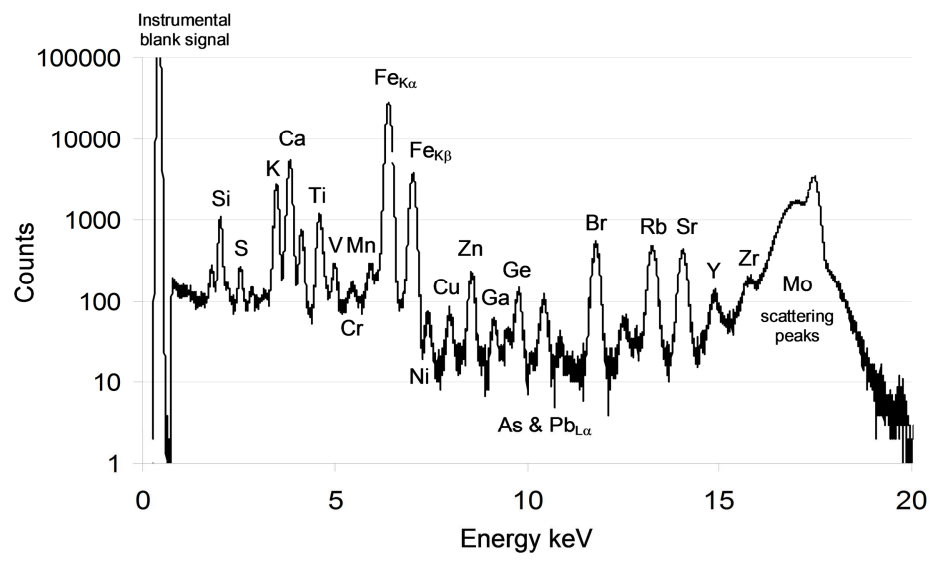

Figure 3. Example of spectrum of one sediment sample obtained with Spectra 6.2. Bruker AXS Mycroanalysis and extracted using PyMca 4.5.0. 

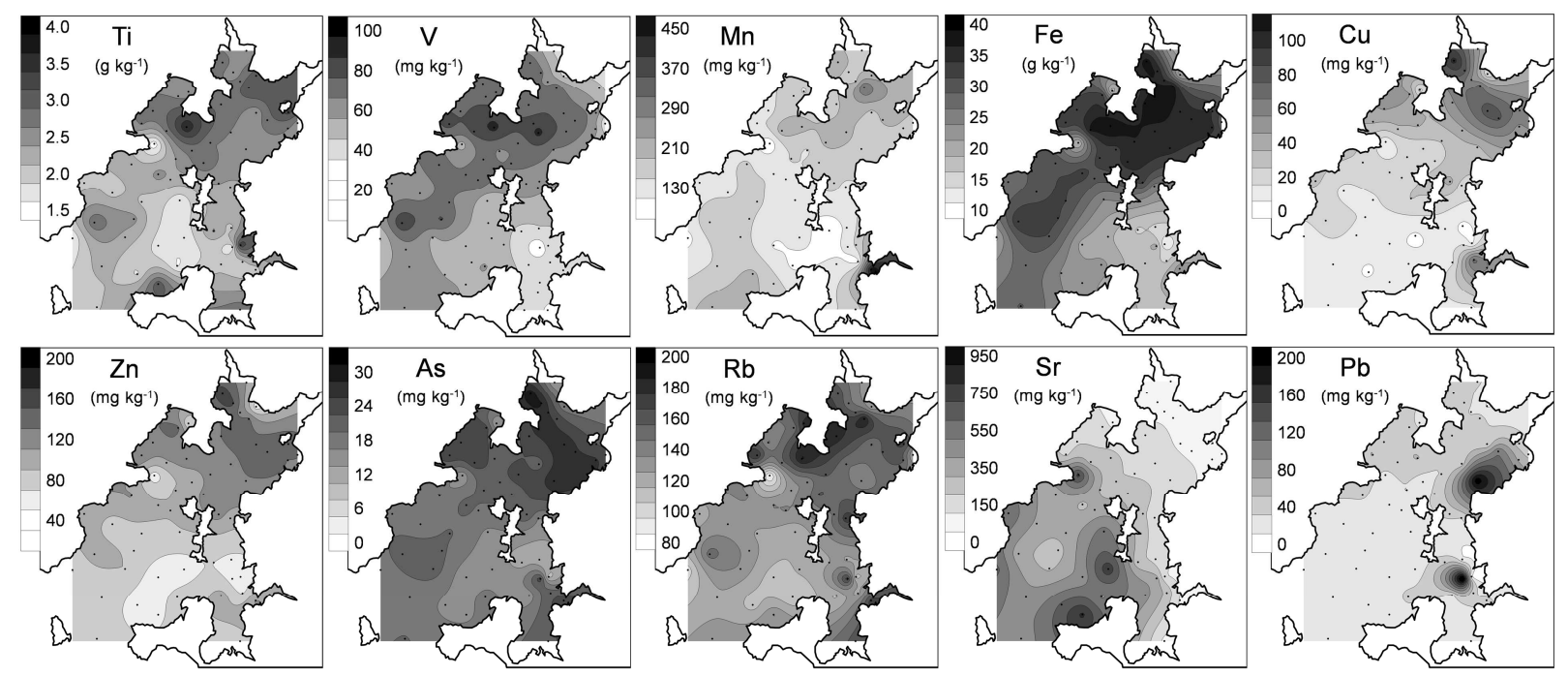

Figure 4. Distribution of nine metals and As in the surface sediments of the Ria of Arousa from their analysis by TXRF. Isoline maps were drawn with Surfer 9 software. 


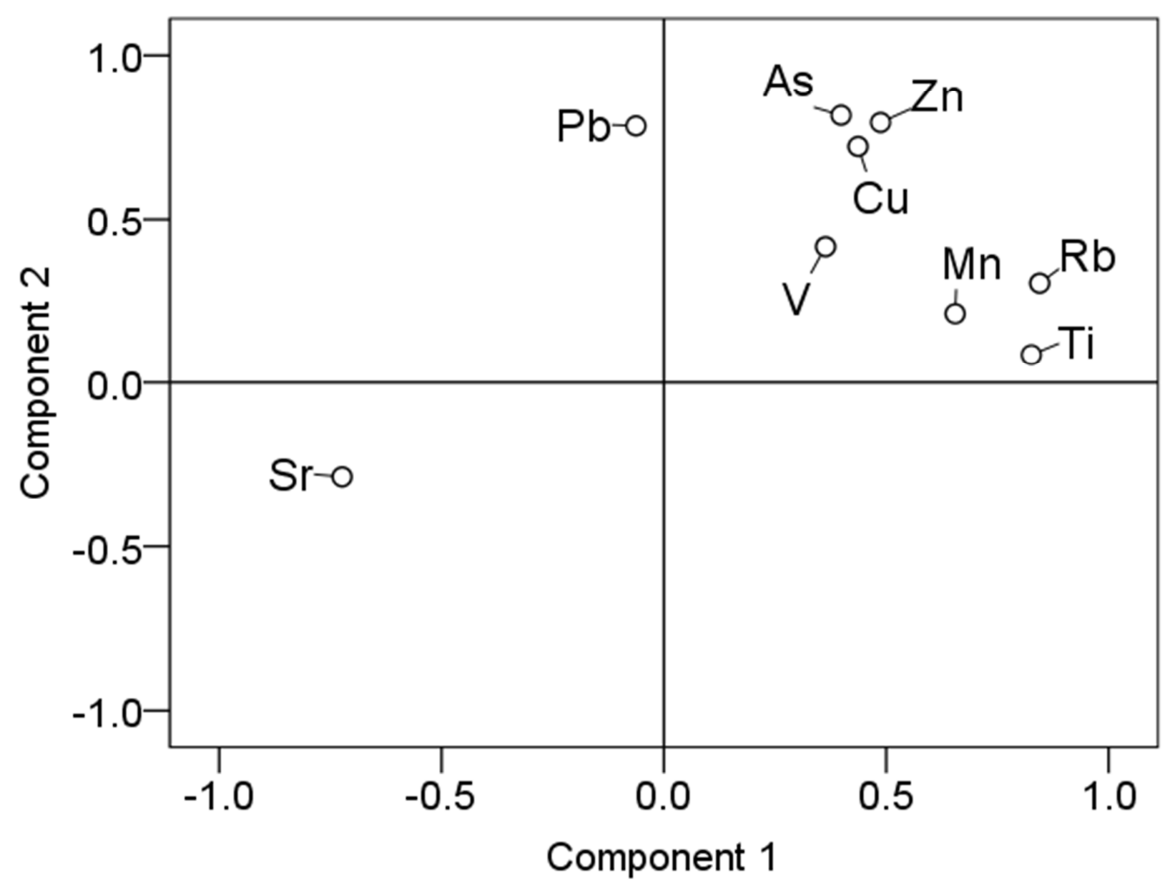

Figure 5. Component plot from the Principal Component Analysis (PCA), using SPSS software, applied to the elements determined in the surface sediment of the Ria of Arousa. 

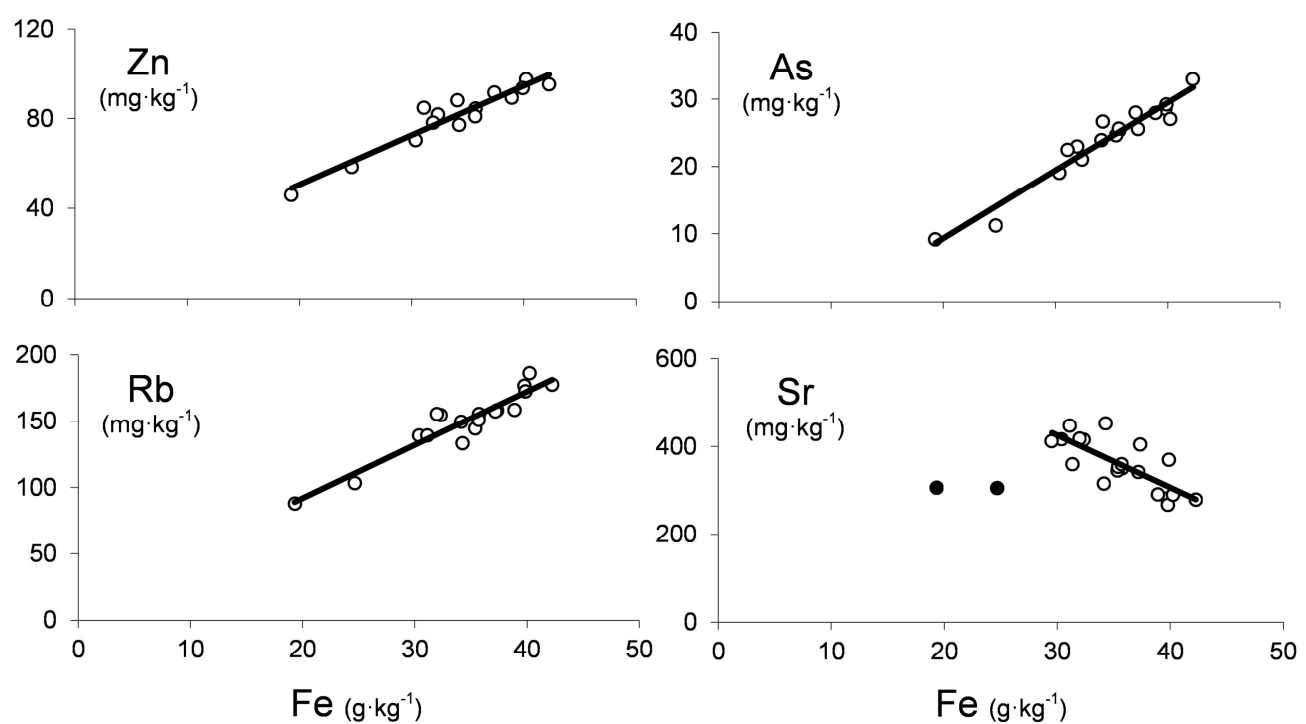

Figure 6. Examples of element-Iron normalization from two sediment cores collected in the Ria of Arousa. The straight lines represent the background value according to Fe content. 


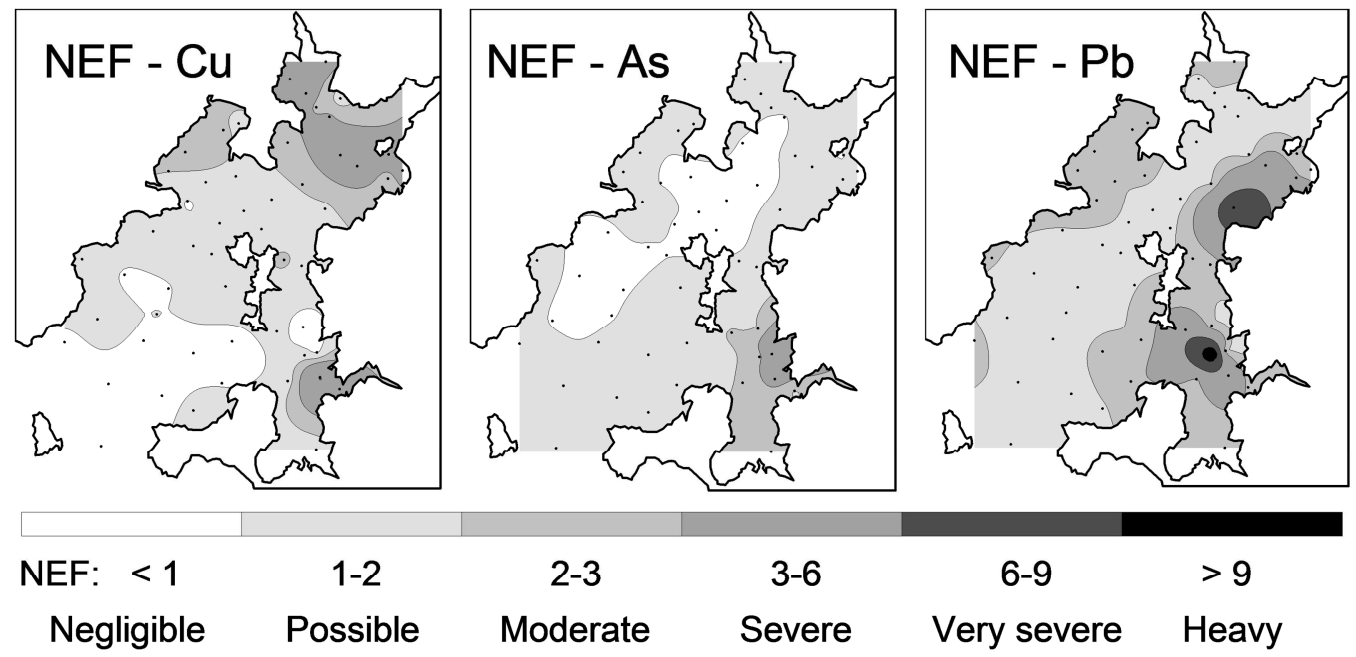

Figure 7. Spatial distribution of the contamination state of $\mathrm{Cu}, \mathrm{As}$ and $\mathrm{Pb}$ in the surface sediment of the Ria of Arousa. Normalized enrichment factors (NEF) were mapped with Surfer 9 software. 